\title{
Coastal versus open-ocean denitrification in the Arabian Sea
}

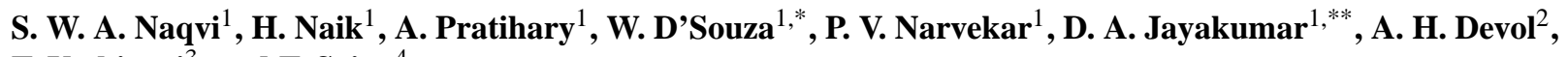 \\ T. Yoshinari ${ }^{3}$, and T. Saino ${ }^{4}$ \\ ${ }^{1}$ National Institute of Oceanography, Dona Paula, Goa 403 004, India \\ ${ }^{2}$ School of Oceanography, University of Washington, Seattle, WA 98195 , USA \\ ${ }^{3}$ Wadsworth Center, New York State Department of Health, P.O. Box 509, Albany, New York 12201, USA \\ ${ }^{4}$ Hydrospheric Atmospheric Research Center, Nagoya University, Furo-cho, Chikusa-ku, Nagoya, 464-8601, Japan \\ * now at: National Centre for Antarctic and Ocean Research, Headland Sada, Vasco da Gama, Goa 403 804, India \\ ** now at: Department of Geosciences, Princeton University, Goyet Hall, Princeton, NJ 98544, USA
}

Received: 4 April 2006 - Published in Biogeosciences Discuss.: 19 June 2006

Revised: 27 November 2006 - Accepted: 4 December 2006 - Published: 14 December 2006

\begin{abstract}
The Arabian Sea contains one of the three major open-ocean denitrification zones in the world. In addition, pelagic denitrification also occurs over the inner and midshelf off the west coast of India. The major differences between the two environments are highlighted using the available data. The perennial open-ocean system occupies two orders of magnitude larger volume than the seasonal coastal system, however, the latter offers more extreme conditions (greater nitrate consumption leading to complete anoxia). Unlike the open-ocean system, the coastal system seems to have undergone a change (i.e., it has intensified) over the past few decades presumably due to enhanced nutrient loading from land. The two systems also differ from each other with regard to the modes of nitrous oxide $\left(\mathrm{N}_{2} \mathrm{O}\right)$ production: In the open-ocean suboxic zone, an accumulation of secondary nitrite $\left(\mathrm{NO}_{2}^{-}\right)$is invariably accompanied by depletion of $\mathrm{N}_{2} \mathrm{O}$ whereas in the coastal suboxic zone high $\mathrm{NO}_{2}^{-}$and very high $\mathrm{N}_{2} \mathrm{O}$ concentrations frequently co-occur, indicating, respectively, net consumption and net production of $\mathrm{N}_{2} \mathrm{O}$ by denitrifiers. The extents of heavier isotope enrichment in the combined nitrate and nitrite $\left(\mathrm{NO}_{3}^{-}+\mathrm{NO}_{2}^{-}\right)$pool and in $\mathrm{N}_{2} \mathrm{O}$ in reducing waters appear to be considerably smaller in the coastal region, reflecting more varied sources/sinks and/or different isotopic fractionation factors.
\end{abstract}

\section{Introduction}

Being a polyvalent element, the speciation, transformations and fluxes of nitrogen in aquatic environments are greatly

Correspondence to: S. W. A. Naqvi

(naqvi@nio.org) affected by the ambient oxygen $\left(\mathrm{O}_{2}\right)$ concentration. As seawater is generally oxygenated, fixed nitrogen in the ocean largely ends up in the most oxidized $(+5)$ state, viz. nitrate ions $\left(\mathrm{NO}_{3}^{-}\right)$, and it is only in sediments and in parts of the water column in a few well-demarcated regions that dissolved $\mathrm{O}_{2}$ gets almost completely depleted to allow microbial conversion of $\mathrm{NO}_{3}^{-}$to molecular nitrogen $\left(\mathrm{N}_{2}\right)$; this process, denitrification, is the most important pathway of losses of fixed nitrogen, and thus a key player in the nitrogen budget (Deuser, 1975; Hattori, 1983; Codispoti and Christensen, 1985). In the Atlantic and Pacific Oceans, such $\mathrm{O}_{2}$-deficient zones (ODZs) occur at mid-depths beneath the productive tropical eastern boundary upwelling zones. What distinguishes the Indian Ocean from the two other oceans is that the most intense ODZ here is located in the northern region, especially in the Arabian Sea. This anomaly, like other distinguishing features of the Indian Ocean, arises from its unusual geography, i.e. mainly the presence of Asian landmass that restricts its northern expanse to the tropics and, to a smaller extent, a porous eastern boundary (openings between the Indonesian islands) which allows exchange of water with the Pacific Ocean at low latitudes. The resultant circulation is not conducive for the development of biologically productive upwelling centres off the coasts of Myanmar and Australia similar to those found off the west coasts of Africa and the Americas. Instead, the most intense upwelling and consequently the highest rates of primary production (PP) at the surface and associated remineralization at depth occur along the northwestern boundary of the Indian Ocean (the Somali and Arabian coasts). Moreover, despite some production of intermediate waters in the Persian Gulf and the Red Sea, subsurface water renewal in the Indian Ocean occurs largely through advection from the south. The waters

Published by Copernicus GmbH on behalf of the European Geosciences Union. 

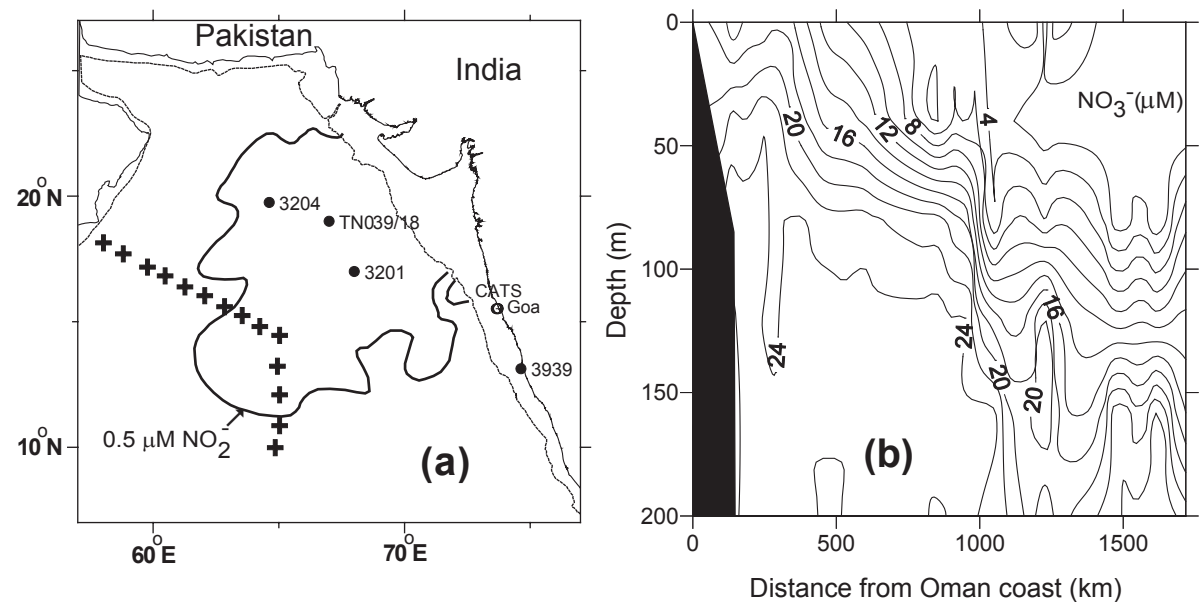

Fig. 1. (a) Geographical limits of the offshore suboxic zone as demarcated by the $0.5 \mu \mathrm{M} \mathrm{NO}_{2}^{-}$contour (redrawn from Naqvi, 1991). Also shown are the stations (marked by crosses) worked during the U.S. JGOFS cruise TN050 (August-September 1995), whose data have been used to construct the $\mathrm{NO}_{3}^{-}$section shown in (b), as well as some other stations (marked by circles) mentioned elsewhere in the paper. Isopleths in (b) and Figs. 2-4 were drawn using Surfer ${ }^{\circledR}$ for Windows version 8 by Golden Software, Inc.

derived from the Southern Hemisphere gradually lose $\mathrm{O}_{2}$ and accumulate products of metabolism $\left(\mathrm{CO}_{2}\right.$, nutrients) during their northward flow. Thus, a lower supply and an enhanced $\mathrm{O}_{2}$ demand combine to produce very intense $\mathrm{O}_{2}$ deficiency (Winkler $\mathrm{O}_{2}<0.1 \mathrm{mLL}^{-1} ; \sim 4 \mu \mathrm{M}$ ) within a very wide depth range $(\sim 100 / 150$ to $1000 \mathrm{~m})$ in the north, particularly in the Northwestern Indian Ocean (Wyrtki, 1971; Sen Gupta and Naqvi, 1984; Naqvi, 1987).

Due to the semi-enclosed nature of the North Indian Ocean, the OMZ impinges upon a very large area of the continental margin: bottom waters with $\mathrm{O}_{2}<0.5 \mathrm{~mL} \mathrm{~L}^{-1}$ $(22 \mu \mathrm{M})$ and $<0.2 \mathrm{mLL}^{-1}(9 \mu \mathrm{M})$, are estimated to cover about $1.15 \times 10^{6}$ and $0.76 \times 10^{6} \mathrm{~km}^{2}$, respectively, of the marginal seafloor in the region, which amount to as much as 59 and 63\%, of the corresponding global areas (Helly and Levin, 2004). Moreover, littoral countries of the North Indian Ocean approximately account for a quarter of the world's human population, which in conjunction with the ongoing rapid economic growth makes the region's coastal environments experiencing $\mathrm{O}_{2}$-deficiency highly vulnerable to human impact. Despite this vulnerability, most previous studies on nitrogen transformations in suboxic waters focused on the open ocean (Bange et al., 2005 and references therein), and it is only in recent years that significance of coastal processes is increasingly being appreciated (Naqvi et al., 2000, 2006a). We describe here factors that differentiate the openocean and coastal suboxic zones making use of a variety of new and some published data.

\section{Processes of formation of coastal and open-ocean sub- oxic $^{1}$ zones}

As stated above, the most intense ODZ, as inferred from the occurrence of a secondary nitrite $\left(\mathrm{NO}_{2}^{-}\right)$maximum $(\mathrm{SNM})$, is located in the generally most productive northwestern part of the Indian Ocean. However, within the Arabian Sea itself, suboxic conditions are not associated with the upwelling systems off Somalia and Arabia; instead, the SNM zone extends toward the southwest into the central Arabian Sea from the northwestern Indian shelf, a region of relatively low PP (Fig. 1a; Naqvi, 1991). This is believed to arise from a more effective subsurface water renewal along the Arabian Sea's western boundary through advection from the south (given that the cross-equatorial exchange of subsurface waters is largely confined in the western Indian Ocean - Swallow, 1984) as well as from the Red Sea and the Persian Gulf. Moreover, the dominance of upper-layer flow by mesoscale eddies, which account for the bulk of the kinetic energy (Flagg and Kim, 1998) and extend to the core of the suboxic zone, may facilitate greater downward diffusion of $\mathrm{O}_{2}$ from the surface in the west. In contrast, the SNM coincides with the zone of the lowest kinetic energy and reduced vertical penetration of the eddy field (Kim et al., 2001). In addition to these physical factors, the availability and utilization of nutrients by phytoplankton and the subsequent vertical flux of organic matter must also contribute to the observed $\mathrm{O}_{2}$

\footnotetext{
${ }^{1}$ We consider "suboxic" to be synonymous with "denitrifying", operationally defined by the existence of the SNM. In the Arabian Sea, as in the eastern Pacific, the SNM is confined to the depth range where colorimetric $\mathrm{O}_{2}$ is below $\sim 0.015 \mathrm{mLL}^{-1}(\sim 0.7 \mu \mathrm{M})$ (Winkler $\mathrm{O}_{2}<\sim 0.1 \mathrm{mLL}^{-1}(\sim 4 \mu \mathrm{M})$; Cline and Richards, 1972; Morrison et al., 1999).
} 
distribution. Kim et al. (2001) opined that the route of offshore transport of the nutrient-rich upwelled water (occurring predominantly through filaments and plumes) is such that the denitrification zone receives more nutrients/organic matter than the region located to its south and west. They emphasized the importance of the Ras al Hadd Jet that transports upwelled water first along the northeast Omani coast and then away from the coast off the cape it has been named after. Nutrient distributions during the upwelling season (e.g. for $\mathrm{NO}_{3}^{-}$; Fig. 1b) do indeed indicate long-distance $(\geq 1000 \mathrm{~km})$ transport of the upwelled water reaching well within the region of the most intense $\mathrm{O}_{2}$ deficiency, but the generallyobserved gradual offshore decrease in surface nutrient concentration is not supportive of this view. Moreover, the sediment trap data clearly show that the flux of particulate organic matter to the deep sea is higher in the western Arabian Sea than in the central and eastern Arabian Sea (Rixen et al., 2005).

Recent results of modeling (Wiggert et al., 2006) as well as observations (Naqvi et al., unpublished manuscript) suggest that, contrary to the prevalent belief, PP in the western Arabian Sea might sometimes be limited by iron instead of nitrogen during the southwest (SW) monsoon. Aerosol analysis during the SW monsoon also revealed very low (below detection limit) concentrations of the labile-Fe(II) off the central Omani coast, presumably because the air masses during this season come from the pristine southern hemisphere (Sierfert et al., 1999). These results have important implications for the composition of phytoplankton and the vertical scale of organic matter degradation. Iron deficiency has been known to cause an increase in ratio of Si:N uptake by diatoms (Hutchins and Bruland, 1998) facilitating greater offshore transport of $\mathrm{NO}_{3}^{-}$. A more rapid depletion of silicate is expected to cause a shift in phytoplankton community structure with increasing abundance of smaller autotrophs offshore, which is in accordance with observations (Garrison et al., 1998). During the northeast (NE) monsoon the central Arabian Sea experiences convective mixing that penetrates, at the most, to a depth of $125 \mathrm{~m}$ (Banse, 1984, 1987). The depthwise nutrient distribution in the region is such that vertical mixing brings up substantial amounts of $\mathrm{NO}_{3}^{-}$to the euphotic zone but not much silicate, thereby limiting diatom productivity (Naqvi et al., 2002). Thus, PP in the open central Arabian Sea seems to be dominated by small, non-diatomaceous autotrophs during both the SW and NE monsoons. The organic matter produced by these organisms would be degraded at shallower depths relative to that produced by diatoms. Therefore, one would expect the average depth of remineralization of material exported from the surface layer to shoal up with increasing distance from the coast, such that more material is degraded close to the core of the $\mathrm{O}_{2}$ minimum zone in the offshore region. This is consistent with the observed $\mathrm{O}_{2}$ distribution (Naqvi et al., unpublished manuscript).
It must, however, be pointed out that despite the absence of the SNM in the western Arabian Sea, high concentrations of elements that are more soluble in the reduced states (e.g. Fe and $\mathrm{Mn}$ ) and of the reduced species (such as $\mathrm{I}^{-}$) can still occur within the core of the $\mathrm{O}_{2}$ minimum (Saager et al., 1989; Farrenkopf et al., 1997; Farrenkopf and Luther, 2002). Farrenkopf et al. (1997) and Farrenkopf and Luther (2002) ascribed the elevated $\mathrm{I}^{-}$levels, at least in part, to heterotrophic iodate $\left(\mathrm{IO}_{3}^{-}\right.$) reduction and Bange et al. (2001) postulated that the associated thermodynamically-feasible oxidation of ammonium $\left(\mathrm{NH}_{4}^{+}\right)$by $\mathrm{IO}_{3}^{-}$could produce $\mathrm{N}_{2} \mathrm{O} . \mathrm{N}_{2} \mathrm{O}$ is probably also formed through nitrifier denitrification in these waters (Shailaja et al., 2006). However, it is unlikely that the production of $\mathrm{N}_{2}$ and $\mathrm{N}_{2} \mathrm{O}$ through canonical denitrification is quantitatively very important outside the SNM zone.

The development of suboxic conditions over the Indian shelf is related in a general way to the prevalence of largescale, mesopelagic, open-ocean $\mathrm{O}_{2}$ deficiency, because the latter is the source of water that upwells over the Indian shelf during the SW monsoon. Nevertheless, the open-ocean and coastal suboxic zones are not contiguous. This is due to the presence of the West India Undercurrent (WIUC) that flows northward while the surface flow is toward the south. The WIUC may be identified just off the continental shelf/slope from the distribution of temperature (upward sloping of isotherms at the top of this feature and downward tilt close to its bottom; Fig. 2a), and even more clearly from those of salinity and $\mathrm{O}_{2}$ (Figs. 2b, c). Note that the water derived from the south has lower salinity and slightly higher $\mathrm{O}_{2}$ content. As judged by the 35400 salinity contour, the influence of the undercurrent, at its peak, extends vertically down to approximately $400 \mathrm{~m}$ depth and horizontally up to $200 \mathrm{~km}$ from the continental slope at $15^{\circ} \mathrm{N}$ latitude (Fig. 2b). Even though seasonally variable, the WIUC is very important for determining the redox status of subsurface waters since it is a source of $\mathrm{O}_{2}$ to the otherwise suboxic mesopelagic zone that prevents the water from turning denitrifying off the continental margin probably as far north as $17^{\circ} \mathrm{N}$ latitude. Consequently, as reflected by the distribution of $\mathrm{NO}_{2}^{-}$(Fig. 2d), denitrification intensifies away from the coast. This pattern is opposite to that observed in the two other major oceanic suboxic zones, especially off Peru-Chile, where the poleward undercurrents, in fact, support bulk of the denitrification (Codispoti et al., 1989). This difference probably owes to a lower respiration rate within the WIUC, which, in turn, may be caused by two factors. Firstly, unlike its counterpart off Peru-Chile the WIUC does not occur over the shelf but along the continental slope, and secondly, except in the most southern part, upwelling along the west coast of India is by and large confined to a narrow strip over the inner shelf such that surface waters directly overhead of the WIUC are not very productive. As the water upwells and moves shoreward, rapid increase in respiration depletes its already low $\mathrm{O}_{2}$ content, culminating in the seasonal development of reducing conditions (denitrification followed by 

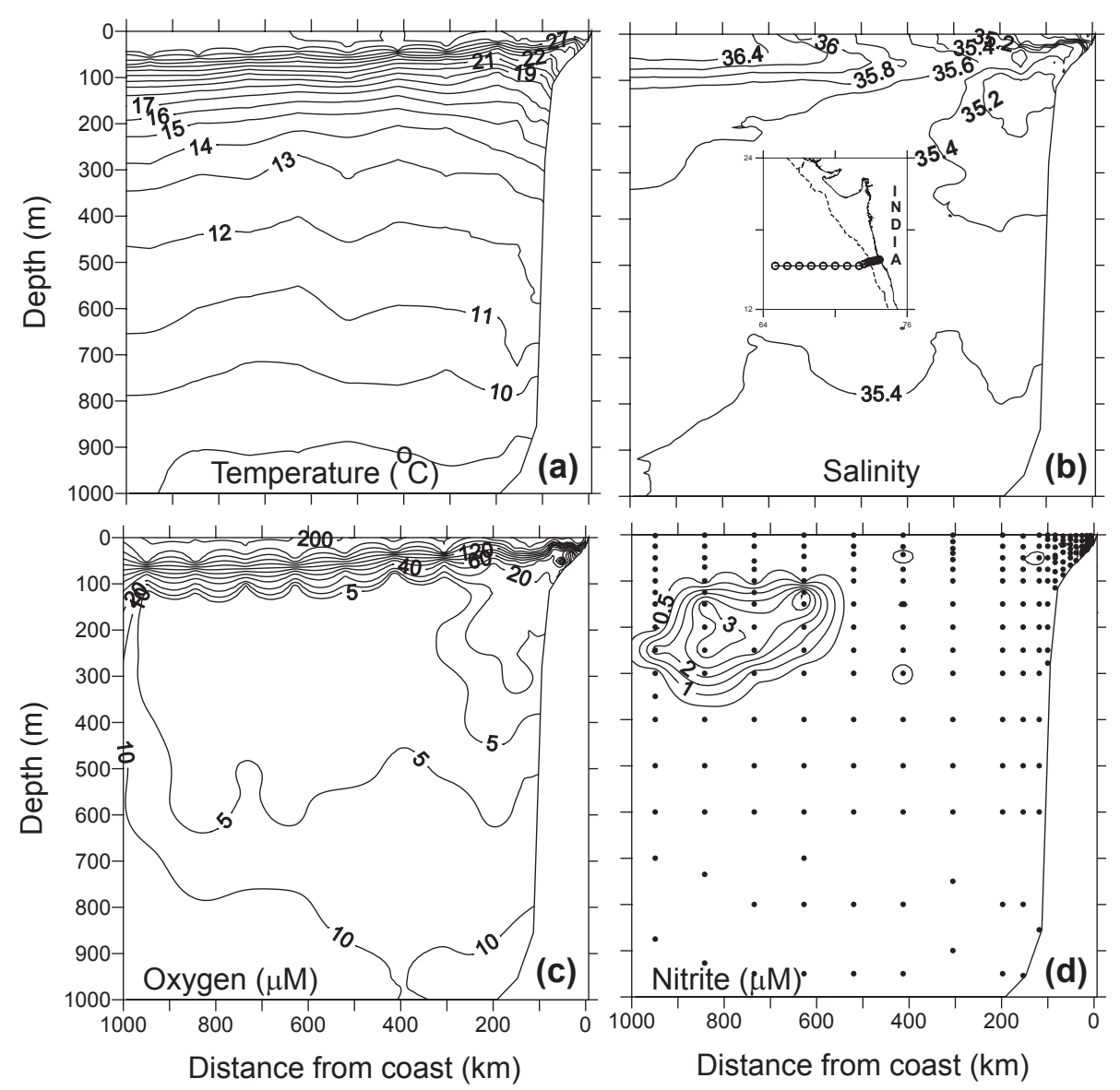

Fig. 2. Variations in (a) temperature, (b) salinity, (c) $\mathrm{O}_{2}$, and (d) $\mathrm{NO}_{2}^{-}$in the upper $1 \mathrm{~km}$ off Goa (see inset in (b) for station locations) during 1-6 December 1998. Modified from Naqvi et al. (2006a).

sulphate $\left(\mathrm{SO}_{4}^{2-}\right)$ reduction) over the mid- and inner-shelf regions (e.g. Fig. 3) covering a wide latitudinal range (between at least 12 and $20^{\circ} \mathrm{N}$, probably extending further north to the Pakistani coast).

\section{Seasonality of $\mathrm{O}_{2}$ deficiency}

The main difference between the open-ocean and coastal suboxic zones is that while the former is perennial, the latter occurs only during and shortly after the SW monsoon. The open-ocean suboxic zone is also influenced by monsoonal changes, albeit to a smaller extent, that should be related to both the $\mathrm{O}_{2}$ supply and consumption within the ODZ. For example, surveys carried out during consecutive SW and NE monsoon seasons (1987 to 1988) led Naqvi et al. (1990) to suggest a more vigorous denitrification (inferred from higher $\mathrm{NO}_{2}^{-}$concentrations) during the latter season, a finding subsequently supported by the observations of de Sousa et al. (1996) made in 1996. Morrison et al. (1998, 1999) also found substantial variability in the depth profiles of $\mathrm{NO}_{2}^{-}$but without a clear seasonal trend within 100 to
$600 \mathrm{~m}$ at stations occupied repeatedly during the U.S. JGOFS expedition in 1994-1995. In any case, the substantial shortterm changes evident in these data sets imply that the intermediate waters in the Arabian Sea must be quickly renewed (Swallow, 1984; Naqvi, 1987; Somasundar and Naqvi, 1988; Naqvi and Shailaja, 1993).

The temporal evolution of suboxic conditions over the western Indian shelf is intimately linked to the seasonal reversal of surface circulation. During the NE monsoon, the West India Coastal Current (WICC) carries warmer, fresher waters of equatorial origin toward the north. The low concentrations of nutrients coupled with downwelling associated with this flow result in low productivity and relatively deep mixed layers so that the shelf waters are generally well oxygenated. In contrast, circulation during the SW monsoon is characterized by an equatorward surface current, the abovementioned poleward WIUC and coastal upwelling typical of oceanic eastern boundaries. However, upwelling along the Indian west coast is nowhere as vigorous as along the coasts of Somalia, Yemen and Oman in the western Arabian Sea. Moreover, due to the presence of a warm, low-salinity lens - formed through intense precipitation in the coastal zone - 

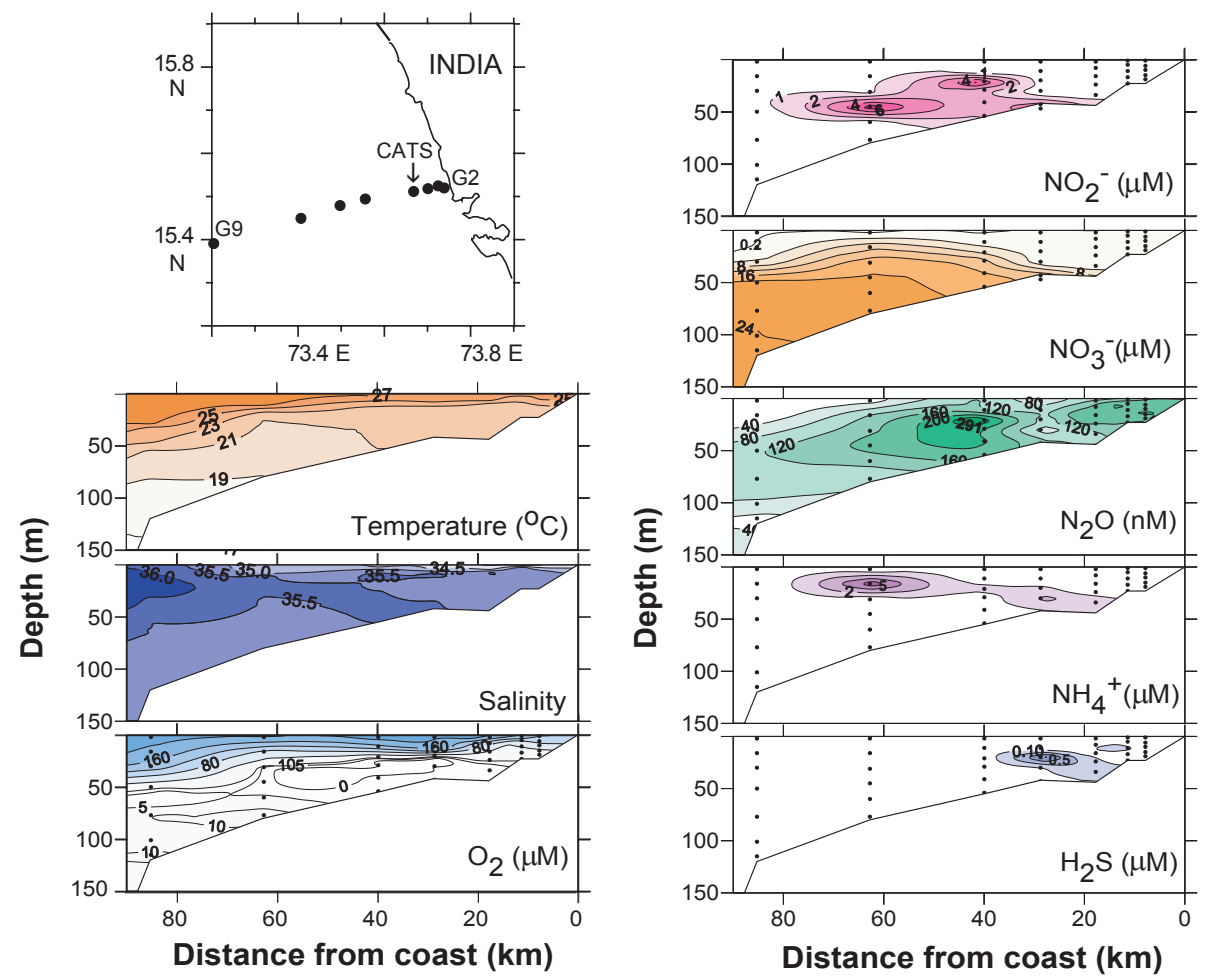

Fig. 3. Vertical sections of temperature, salinity, $\mathrm{O}_{2}$, inorganic nitrogen species and hydrogen sulphide off Goa during 9 to 10 October 1999. Station locations are shown in the accompanying map for this frequently-sampled, shallower part of the Goa transect also shown in Fig. 2. These data are hitherto unpublished.

the upwelled water rarely comes in contact with the atmosphere, and the resultant strong thermohaline stratification contributes to the sustenance of very severe $\mathrm{O}_{2}$-depletion very close (within few metres) to the sea surface. The $\mathrm{O}_{2}$ deficiency begins with the advent of upwelling sometime in April-May and intensifies gradually with time. Off Goa, where sufficient data exist due to quasi-time series monitoring of a station (the Candolim Time Series, CATS) over the inner shelf since 1997, near-bottom $\mathrm{O}_{2}$ concentrations reach suboxic levels in August as evident by the accumulation of $\mathrm{NO}_{2}^{-}$and the depletion of $\mathrm{NO}_{3}^{-}$(Fig. 4). Complete loss of the oxidized nitrogen species is followed by the $\mathrm{SO}_{4}^{2-}$ reduction in September-October. With the reversal of surface currents, oxic conditions are re-established in November-December. When the reducing conditions are at their peak in SeptemberOctober, the cross-shelf sections north of about $12^{\circ} \mathrm{N}$ latitude (e.g. Fig. 3) show the classical sequence of utilization of electron acceptors: $\mathrm{O}_{2}$ over and beyond the outer shelf, $\mathrm{NO}_{3}^{-}$over the mid-shelf and $\mathrm{SO}_{4}^{2-}$ over the inner shelf. This is perhaps the only known region along an open coast where all three types of redox environments are found on the same shelf segment in such an organized manner.

\section{Denitrification rates}

Rates of water-column denitrification in the Arabian Sea have been determined recently by Devol et al. (2006a) through on-deck and in-situ incubations of water samples spiked with ${ }^{15} \mathrm{NO}_{3}^{-}$and measuring the production of ${ }^{15} \mathrm{~N}$ labelled $\mathrm{N}_{2}$. As expected, the rates for the offshore suboxic zone $\left(8.8 \pm 3.8 \mathrm{nmol} \mathrm{N} \mathrm{L} \mathrm{N}^{-1} \mathrm{~d}^{-1} ; \mathrm{n}=15\right)$ are lower than those for the shallower system $\left(21.6 \pm 46.8 \mathrm{nmol} \mathrm{N} \mathrm{L} \mathrm{L}^{-1} \mathrm{~d}^{-1}\right.$; $\mathrm{n}=15)$. Although the overall rate for the offshore suboxic zone $\left(\sim 41 \mathrm{Tg} \mathrm{N} \mathrm{y}{ }^{-1}\right)$ derived from these data is within the range (10 to $44 \mathrm{Tg} \mathrm{N} \mathrm{y}^{-1}$ ) of previous estimates for denitrification in the region based on stoichiometric calculations (Naqvi, 1987; Mantoura et al., 1993) and electron transport system (ETS) activity (Naqvi and Shailaja, 1993), it still suffers from considerable uncertainty for the following reasons. Firstly, recent research has demonstrated that, in addition to canonical denitrification, the anaerobic ammonium oxidation (anammox; the reaction of $\mathrm{NH}_{4}^{+}$with $\mathrm{NO}_{2}^{-}$) is an important process of $\mathrm{N}_{2}$ formation; in fact, in most of the cases examined so far, the latter pathway has been found to be dominant (Kuypers et al., 2003, 2005; Thamdrup et al., 2006). Thus, incubations with ${ }^{15} \mathrm{NO}_{3}^{-}$alone might lead to an underestimation of $\mathrm{N}_{2}$ production. Secondly, measurements of the $\mathrm{N}_{2} / \mathrm{Ar}$ ratio in seawater have yielded estimates of "excess" $\mathrm{N}_{2}$ that are up to twice the corresponding $\mathrm{NO}_{3}^{-}$deficits 

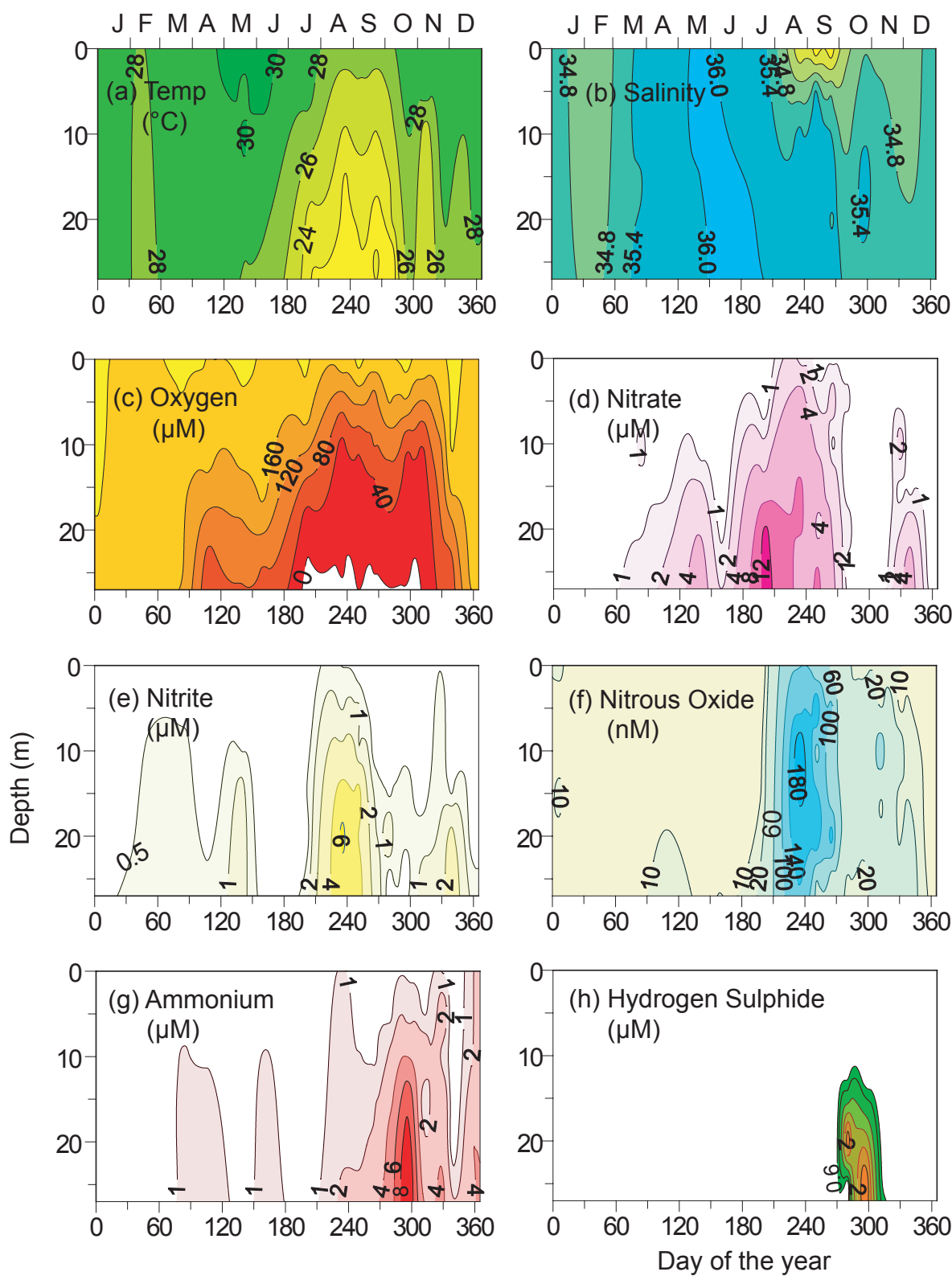

Fig. 4. Monthly-/fortnightly-averaged records showing annual cycle of (a) temperature, (b) salinity, (c) oxygen, (d-g) inorganic nitrogen species, and (h) hydrogen sulphide at the Candolim Time Series (CATS) site (15 $31^{\prime}$ N, $73^{\circ} 39^{\prime}$ E; Fig. 3) based on observations from 1997 to 2004. Modified from Naqvi et al. (2006a).

(the deficiency in $\mathrm{NO}_{3}^{-}$with reference to the concentration expected from the Redfield stoichiometry; Codispoti et al., 2001; Devol et al., 2006a, b; Fig. 5). Although it is possible that sedimentary denitrification contributes to some extent to the observed $\mathrm{N}_{2}$ excess, the two potentially more important processes causing the discrepancy are anammox and mineralization within the OMZ of organic matter produced by nitrogen fixers that has non-Redfieldian elemental composition (N:P $\gg 16)$ (Codispoti et al., 2001; Devol et al., 2006a, b; Codispoti, 2006). It would thus appear that the current estimates for $\mathrm{N}_{2}$ production in the open-ocean suboxic zone should be conservative. This is probably also true, perhaps even more so, for estimates from the coastal suboxic zone. The upwelled water has a $\mathrm{NO}_{3}^{-}$content in excess of $20 \mu \mathrm{M}$, and it takes about a month for the $\mathrm{NO}_{3}^{-}$to be completely lost after the onset of denitrification, indicating that the actual $\mathrm{NO}_{3}^{-}$consumption rate should be far in excess of that measured by the ${ }^{15} \mathrm{NO}_{3}^{-}$incubation method. Repeat observations at several sites over the inner shelf off the central west coast of India suggested an average $\mathrm{NO}_{3}^{-}$consumption rate of $0.83 \mu \mathrm{mol} \mathrm{L}^{-1} \mathrm{~d}^{-1}$, and applying this rate to an estimated 
volume of 1.2 to $3.6 \times 10^{12} \mathrm{~m}^{3}$ yields an overall loss of 1.3 to $3.8 \mathrm{Tg} \mathrm{N} \mathrm{y}^{-1}$ (Naik, $2003^{2}$ ). This is only 3 to $9 \%$ of the denitrification rate estimated for the perennial suboxic zone of the open Arabian Sea.

It is very likely that even the relatively modest rate over the Indian shelf has been anthropogenically enhanced over the past few decades. Sulphate $\left(\mathrm{SO}_{4}^{2-}\right)$ reduction has been found to recur every year at the CATS site ever since the monitoring began in 1997. The data show substantial intraseasonal as well as inter-annual variations, the latter without a clear secular trend. However, there is no indication of occurrence of this process in the historical data sets from anywhere along the Indian west coast. For example, an extensive set of hydrocast data for salinity, temperature and $\mathrm{O}_{2}$ along numerous cross-shelf sections was generated under the UNDP/FAO-sponsored Integrated Fisheries Project (IFP) during 1971-1975 covering different seasons. In the region off Karwar (just south of Goa), a comparison of the $\mathrm{O}_{2}$ data from these cruises with those generated by us from 1997 to 2004 shows a significant decrease in near-bottom $\mathrm{O}_{2}$ over the inner- and mid-shelf (depth $<60 \mathrm{~m}$ ) for the period August-October (Naqvi et al., 2006a). Even though hydrogen sulphide $\left(\mathrm{H}_{2} \mathrm{~S}\right)$ was not measured on the IFP cruises, the absence of zero Winkler oxygens in the IFP data set indicates that it was probably not present. Other data taken subsequently also suggest that the subsurface environment was denitrifying, but not $\mathrm{SO}_{4}^{2-}$ reducing, at least until the 1980s (Naqvi et al., 2000). Thus, the subsurface $\mathrm{O}_{2}$ deficiency over the Indian shelf seems to have intensified significantly since the 1970s. Although the cause of this change cannot be pinpointed with absolute certainty, it is most likely related to an increased nitrogen loading from land (Naqvi et al., 2000). Indeed, fertilizer consumption in the region has undergone an order of magnitude increase over the past few decades, and this is expected to have affected river runoff. However, the available data suggest a modest riverine flux $(0.1 \mathrm{Tg} \mathrm{N}$ $\mathrm{y}^{-1}$ ) of dissolved inorganic nitrogen (DIN) to the Arabian Sea (Naqvi et al., 2006b). The deposition rate from the atmosphere is perhaps relatively more important. Bange et al. (2000) estimated a total DIN deposition of $\sim 1.6 \mathrm{Tg} \mathrm{y}^{-1}$ for the region north of $6^{\circ} \mathrm{N}$ latitude, and although this is based on observations offshore, the flux density is expected to be higher over the Indian shelf. It would be reasonable to assume that most of the aeolian and riverine inputs are of anthropogenic origin, which could account for a significant fraction of denitrification rate over the shelf estimated above, and the shift from natural suboxic to anthropogenic anoxic conditions. This is because the stoichiometries of primary production $(\mathrm{C}: \mathrm{N}=6.6)$ and denitrification $(\mathrm{C}: \mathrm{N}=1.1)$ are such that new inputs of DIN into suboxic waters get amplified by

\footnotetext{
${ }^{2}$ Naik, H.: Benthic nitrogen cycling with special reference to nitrous oxide in the coastal and continental shelf environments of the eastern Arabian Sea, Ph.D. thesis, Goa University, unpublished, 147 pp., 2003.
}

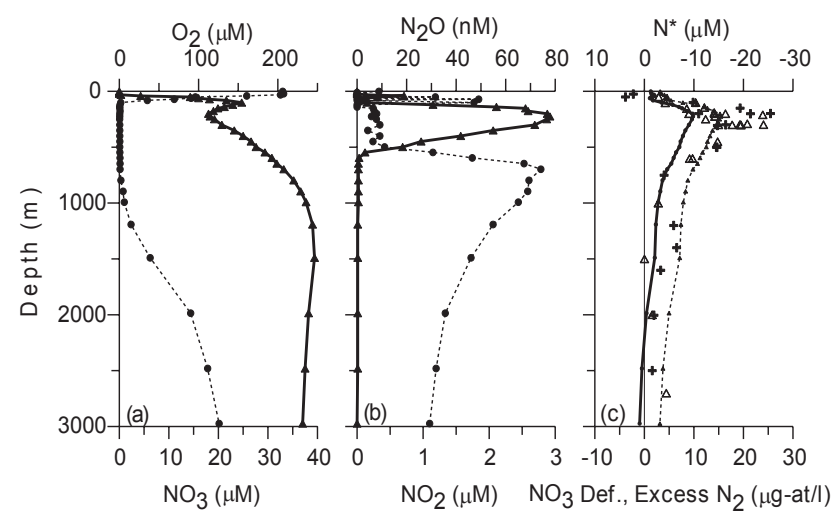

Fig. 5. Vertical profiles of properties at $19^{\circ} \mathrm{N}, 67^{\circ} \mathrm{E}$ (all data except for $\mathrm{N}_{2} /$ Ar collected on TN039 cruise of U.S. JGOFS (Sta. 18; Fig. 1) on 1-2 October 1994). (a) $\mathrm{O}_{2}$ (circles) and $\mathrm{NO}_{3}^{-}$(triangles); (b) $\mathrm{N}_{2} \mathrm{O}$ (circles) and $\mathrm{NO}_{2}^{-}$(triangles); (c) $\mathrm{NO}_{3}^{-}$deficit according to Codispoti et al. (2001) (dots connected by the solid line), $\mathrm{N}^{*}$ according to Gruber and Sarmiento (2002) (small filled triangles connected by the dashed line), and "excess $\mathrm{N}_{2}$ " calculated from the $\mathrm{N}_{2}$ /Ar ratio (larger unconnected symbols - crosses for data collected on two different cruises from this station and triangles for those from other stations also located within the denitrification zone). $\mathrm{N}_{2} / \mathrm{Ar}$ data are from Devol et al. (2006a).

a factor of up to 6 (Codispoti et al., 2001). That is, for each unit of DIN added to the surface waters up to 6 units of $\mathrm{NO}_{3}^{-}$ can be removed at depth if the additional organic matter produced is oxidized by $\mathrm{NO}_{3}^{-}$, thereby making subsurface denitrification very sensitive to the external DIN loading.

\section{Nitrous oxide cycling}

The distribution pattern of $\mathrm{N}_{2} \mathrm{O}$ in the water column in the open Arabian Sea is similar to that observed in other areas containing intense ODZs: Within the denitrifying zone $\mathrm{N}_{2} \mathrm{O}$ concentrations are invariably below $\sim 10 \mathrm{nM}$ with peak values exceeding $40 \mathrm{nM}$ occurring at the oxic-suboxic interfaces; outside the denitrification zone a single broad $\mathrm{N}_{2} \mathrm{O}$ maximum is associated with the $\mathrm{O}_{2}$ minimum (Law and Owens, 1990; Naqvi and Noronha, 1991; Bange et al., 2001, 2005). The $\mathrm{N}_{2} \mathrm{O}$ minimum associated with the SNM can only result from the conversion of $\mathrm{N}_{2} \mathrm{O}$ to $\mathrm{N}_{2}$ by denitrifiers; in contrast, there are several possible pathways - nitrification, denitrification and a coupling between the two processes that can produce the greatly elevated $\mathrm{N}_{2} \mathrm{O}$ concentrations at the peripheries of the SNM zone. The natural isotope abundance of nitrogen and oxygen provide a measure of the relative importance of these various possibilities. These data reveal minima in both $\delta^{15} \mathrm{~N}$ and $\delta^{18} \mathrm{O}^{3}$ that are coincident with

\footnotetext{
${ }^{3}$ Nitrogen and oxygen isotope ratios of $\mathrm{N}_{2} \mathrm{O}$ throughout this paper are expressed as per mil deviations from atmospheric $\mathrm{N}_{2}$ and $\mathrm{O}_{2}$, respectively. In the case of oxygen the values against air can
} 


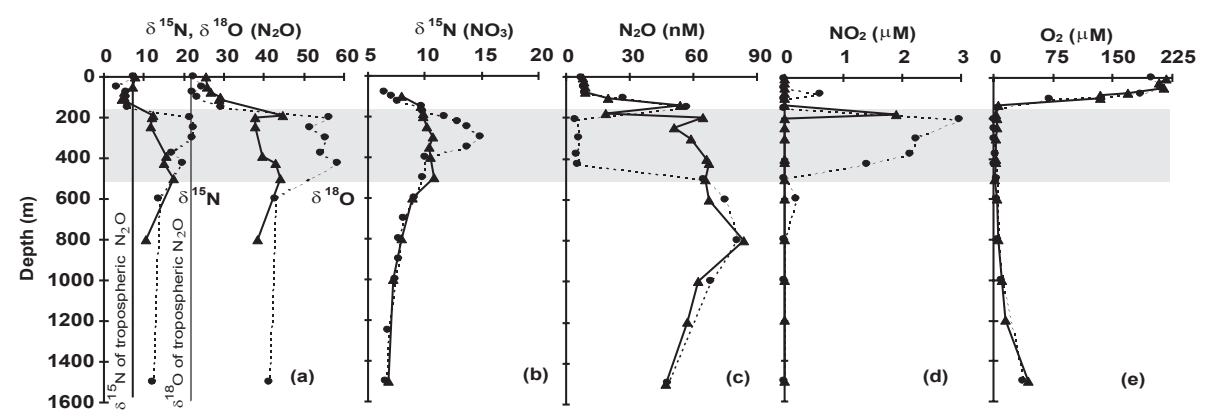

Fig. 6. Vertical profiles of $\delta^{15} \mathrm{~N}$ and $\delta^{18} \mathrm{O}$ (\%o relative to air; see footnote \#3) of $\mathrm{N}_{2} \mathrm{O}(\mathbf{a}), \delta^{15} \mathrm{~N}$ of $\mathrm{NO}_{3}^{-}$(b), and concentrations of $\mathrm{N}_{2} \mathrm{O}$ (c), $\mathrm{NO}_{2}^{-}$(d) and $\mathrm{O}_{2}$ (e) at stations SS $3201\left(17^{\circ} \mathrm{N}, 68^{\circ} \mathrm{E}\right.$; filled circles, joined by dotted lines) and SS $3204\left(19.75^{\circ} \mathrm{N}, 64.62^{\circ} \mathrm{E}\right.$; filled triangles, joined by continuous lines). The shaded region represents the secondary $\mathrm{NO}_{2}^{-}$maximum at SS 3201 . Vertical lines give $\delta^{15} \mathrm{~N}$ and $\delta^{18} \mathrm{O}$ of tropospheric $\mathrm{N}_{2} \mathrm{O}$. Station locations shown in Fig. 1. After Naqvi et al. (1998a).

the upper $\mathrm{N}_{2} \mathrm{O}$ concentration peak (Fig. 6). Such minima, also reported from the Pacific Ocean, are consistent with the nitrification being the major production pathway (Dore et al., 1998). Incidentally, this is the only level where the dissolved $\mathrm{N}_{2} \mathrm{O}$ is isotopically lighter, both for nitrogen and oxygen, than the tropospheric $\mathrm{N}_{2} \mathrm{O}$. The values are understandably heavy - indeed the heaviest reported yet from any oceanic setting - within the SNM zone due to fractionation associated with denitrification (i.e., lighter $\mathrm{N}_{2} \mathrm{O}$ is preferentially utilized by denitrifiers). Intriguingly, the $\delta^{15} \mathrm{~N}$ values for $\mathrm{N}_{2} \mathrm{O}$ exceed those for $\mathrm{NO}_{3}^{-4}$, going against the trend exhibited by cultures of Paracoccus denitrificans grown under steady-state conditions (Barford et al., 1999), which suggested greater fractionation during the reduction of $\mathrm{NO}_{3}^{-}$to $\mathrm{N}_{2} \mathrm{O}(\sim 16 \%$ ) than of $\mathrm{N}_{2} \mathrm{O}$ to $\mathrm{N}_{2}(\sim 13 \%)$. The higher $\delta^{15} \mathrm{~N}$ of $\mathrm{N}_{2} \mathrm{O}$ seems to imply that the natural bacterial populations should have a larger isotopic effect for the final reduction sequence. Moreover, as this trend persists also in the $\mathrm{N}_{2} \mathrm{O}$-rich waters below the SNM (Fig. 6), it necessitates the involvement of denitrification at least in channeling the lighter nitrogen isotope to $\mathrm{N}_{2}$, if not in $\mathrm{N}_{2} \mathrm{O}$ production, well outside the SNM. Based on the analysis of $\mathrm{N}_{2} \mathrm{O}$ isotopomer ratios (site preference of ${ }^{15} \mathrm{~N}$ in the linear $\mathrm{N}_{2} \mathrm{O}$ molecule), Yamagishi et al. (2005) also identified denitrification to be the dominant process responsible for $\mathrm{N}_{2} \mathrm{O}$ production in the $\mathrm{O}_{2}$ minimum zone of the North Pacific. However, since nitrification and denitrification involve common intermediates and occur in close proximity of each other in $\mathrm{O}_{2}$-depleted waters, both in the spatial and temporal domains, the exchange of these intermediates

be converted to the more commonly used SMOW (standard mean ocean water) scale utilizing the equation (Kim and Craig, 1990):

$\delta^{18} \mathrm{O}_{\mathrm{AIR}}=-23.0+\delta^{18} \mathrm{O}_{\mathrm{SMOW}} / 1.0235$

${ }^{4}$ Analysis of isotopic composition of nitrate generally involves its chemical reduction to $\mathrm{NH}_{4}^{+}$, during which process nitrite, if present, is also similarly reduced. The data being reported here, as in all previous studies, thus pertain to the combined $\mathrm{NO}_{3}^{-}$and $\mathrm{NO}_{2}^{-}$pool, but will still be denoted by $\delta^{15} \mathrm{~N}$ of $\mathrm{NO}_{3}^{-}$for convenience hereafter. (nitrification-denitrification coupling) are expected to greatly affect the isotopic composition of $\mathrm{N}_{2} \mathrm{O}$.

The coastal suboxic zone in the Arabian Sea is distinguished by much higher concentrations of $\mathrm{N}_{2} \mathrm{O}$ (reaching up to $\sim 0.8 \mu \mathrm{M}$ ) as compared to the open ocean. The highest values are unexpectedly associated with very high $\mathrm{NO}_{2}^{-}$(reaching up to $16 \mu \mathrm{M}$ ) and low (near exhaustion) $\mathrm{NO}_{3}^{-}$levels often at mid-depths. This trend, observed in most cross-shelf sections (e.g. Fig. 3), has also been recurring at the CATS site (Fig. 4) where peak $\mathrm{N}_{2} \mathrm{O}$ values invariably coincide with rapidly declining $\mathrm{NO}_{3}^{-}$and the build-up of $\mathrm{NO}_{2}^{-}$. The $\mathrm{N}_{2} \mathrm{O}$ concentrations decrease rapidly as the system turns sulphate reducing. This indicates that the observed high concentrations cannot be due to inhibition of $\mathrm{N}_{2} \mathrm{O}$ reductase activity by $\mathrm{H}_{2} \mathrm{~S}$ (Senga et al., 2006). The oxygen concentrations are too low for nitrification to occur in these waters, leaving denitrification as the principal pathway of $\mathrm{N}_{2} \mathrm{O}$ production. These results are completely different from those from the open ocean SNM (Fig. 6). Incubations of water samples collected from the Indian shelf, that were $\mathrm{O}_{2}$-poor but not denitrifying to begin with, revealed transient $\mathrm{N}_{2} \mathrm{O}$ accumulation at micromolar levels once the system turned reducing, and it was hypothesized that frequent aeration due to turbulence in shallow, rapidly-denitrifying systems might suppress the activity of $\mathrm{N}_{2} \mathrm{O}$-reductase leading to a large fraction of nitrogen undergoing bacterial reduction ending up as $\mathrm{N}_{2} \mathrm{O}$ (Naqvi et al., 2000). Because such production occurs within a few metres of the sea surface, the observed surface $\mathrm{N}_{2} \mathrm{O}$ concentrations ( 5 to $436 \mathrm{nM}$, mean $37.3 \mathrm{nM}, \mathrm{n}=241$ ) and the computed emission to the atmosphere $\left(0.05\right.$ to $\left.0.38 \mathrm{Tg} \mathrm{N}_{2} \mathrm{O} \mathrm{y}^{-1}\right)$ are unusually high (Naqvi et al., 2006a).

In spite of the more extreme redox conditions prevailing in the coastal suboxic zone, the ranges of isotopic values for $\mathrm{N}_{2} \mathrm{O}$ are relatively narrow ( -2 to $13 \%$ or for $\delta^{15} \mathrm{~N}$ and 17 to $60 \%$ o for $\delta^{18} \mathrm{O}$ ) over the shelf as compared to the open ocean ( 3 to $81 \%$ or for $\delta^{15} \mathrm{~N}$ and 17 to $95 \%$ or for $\delta^{18} \mathrm{O}$ ) (Yoshinari et al., 1997; Naqvi et al., 1998a, b). This is exemplified by data from a typical coastal site presented in Fig. 7. The 
isothermal, isohaline sub-pycnocline waters at this site had lost most of the oxidized nitrogen (especially in the deepest sample where the loss was almost complete). However, despite large vertical gradient in $\mathrm{N}_{2} \mathrm{O}$ concentration (decrease from the pronounced maximum from the top of the suboxic zone to near-zero concentration close to the sea floor), the $\delta^{15} \mathrm{~N}$ and $\delta^{18} \mathrm{O}$ values did not vary greatly. While, the aforementioned exchange of intermediates between nitrification and denitrification, which is expected to occur to a much larger degree in the more spatially and temporally variable coastal environment, makes the interpretation of isotopic data from the coastal region less straightforward with regard to the pathways of $\mathrm{N}_{2} \mathrm{O}$ cycling, it is quite likely that the observed differences arise from a different fractionation pattern from that observed in the open ocean suboxic zone, as in the case of $\mathrm{NO}_{3}^{-}$, as we shall see in the following section.

\section{Nitrogen isotopic fractionation during denitrification}

Water column distributions of $\delta^{15} \mathrm{~N}$ in $\mathrm{NO}_{3}^{-}$and $\mathrm{N}_{2}$ in the open Arabian Sea exhibit large changes brought about by the microbial consumption/production of these species (Brandes et al., 1998; Naqvi et al., 1998a, b; Altabet et al., 1999). Denitrification has been known to involve pronounced massdependent fractionation (preferential reduction of ${ }^{14} \mathrm{NO}_{3}^{-}$ over ${ }^{15} \mathrm{NO}_{3}^{-}$) in seawater (Cline and Kaplan, 1975), leading to an enrichment of ${ }^{15} \mathrm{~N}$ in the $\mathrm{NO}_{3}^{-}$pool and its depletion in the $\mathrm{N}_{2}$ pool. In the central Arabian Sea, the $\delta^{15} \mathrm{~N}$ of $\mathrm{NO}_{3}^{-}$increases from $\sim 6 \%$ o in deep waters (2500 to $3000 \mathrm{~m}$ ), comparable with values from other areas (Wu et al., 1997; Sigman et al., 1997), to 15 to $18 \%$ o within the core of the denitrifying layer (Fig. 6; Brandes et al., 1998; Altabet et al., 1999 ); the $\delta^{15} \mathrm{~N}$ of $\mathrm{N}_{2}$ concurrently decreases from $\sim 0.6 \%$ o to $\sim 0.2 \%$ o (Brandes et al., 1998). Brandes et al. combined their isotopic data with $\mathrm{NO}_{3}^{-}$deficits (computed from the relationship between the tracer "NO" with potential temperature) and used advection-reaction (Rayleigh distillation) and diffusion-reaction models to compute the isotope fractionation factor $(\varepsilon)$ of $22 \%$ and $25 \%$, respectively. Altabet et al. (1999) obtained a somewhat higher $(\sim 30 \%$ o), value for $\varepsilon$ using $-\mathrm{N}^{*}$ (cf. Gruber and Sarmiento, 1997) and Rayleigh fractionation. The estimates of $\varepsilon$ are about the same for the suboxic zones of the Arabian Sea and the eastern tropical North Pacific (Brandes et al., 1998; Altabet et al., 1999), implying relative constancy of isotopic fractionation in the open ocean. These estimates are also well within the range of those obtained earlier through laboratory cultures of heterotrophic denitrifiers ( $\varepsilon=17$ to $29 \%$; Delwiche and Steyn, 1970; Mariotti et al., 1981; Barford et al., 1999). One important implication of these results is that for anammox to be a major producer of $\mathrm{N}_{2}$ in the open ocean, its effect on isotopic composition of $\mathrm{NO}_{3}^{-}$, about which not much is known at present, should not be too different from that of heterotrophic denitrification.

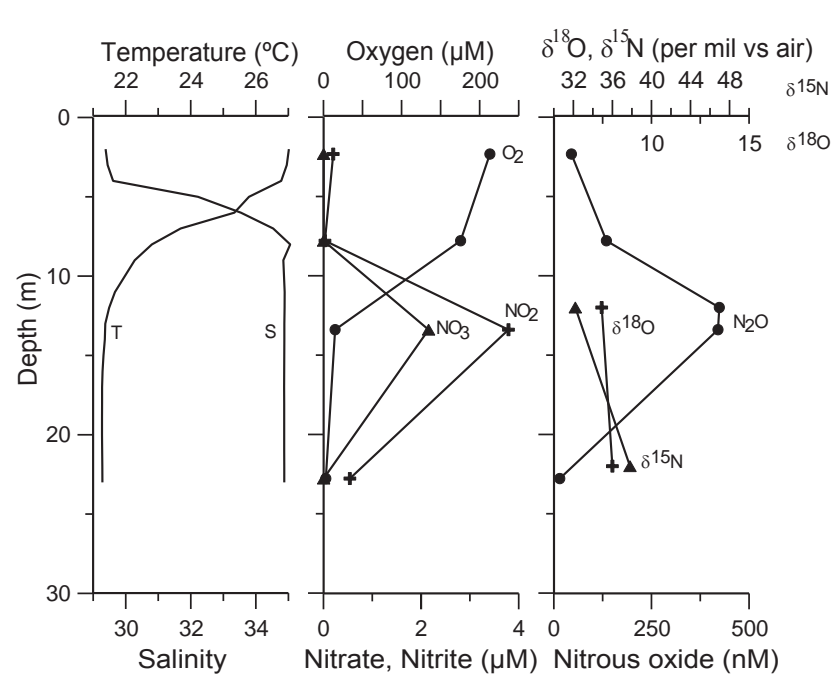

Fig. 7. Vertical profiles of temperature, salinity, dissolved $\mathrm{O}_{2}$, inorganic nitrogen species and $\delta^{15} \mathrm{~N}$ and $\delta^{18} \mathrm{O}$ of $\mathrm{N}_{2} \mathrm{O}$ at Sta. SK $137 / 39\left(9.950^{\circ} \mathrm{N} ; 76.017^{\circ} \mathrm{E}\right.$; Fig. 1) sampled on 8 August 1998. These data are hitherto unpublished.

The isotopic distribution pattern observed in the coastal suboxic zone is quite different, and more variable, from that described above, even though the data are rather limited. These data come from two sets of observations - in August 1997 off Mangalore (Sta. SS 3939; isotopic analysis carried out following Brandes et al., 1998) and in September 2000 off Goa (Stas. G3, G4 and G5; isotopic analysis carried out following Tanaka and Saino, 2002). On both occasions the water column had experienced significant losses of $\mathrm{NO}_{3}^{-}$. Hydrographic and chemical data at Sta. SS 3939 along with the $\delta^{15} \mathrm{~N}^{-\mathrm{NO}_{3}^{-}}$values are plotted against depth in Fig. 8. Temperatures and salinity profiles are typical of this region for the survey period, showing strong near-surface thermohaline stratification and isothermal and isohaline conditions below the shallow pycnocline. Similarly, the two deepest samples experienced near-complete $\mathrm{O}_{2}$ depletion that is characteristic of the sampling period. The $\mathrm{NO}_{3}^{-}$profile exhibited a mid-depth maximum below which concentrations decreased while the $\mathrm{NO}_{2}^{-}$concentrations showed a concomitant increase with depth. $\mathrm{NO}_{3}^{-}$deficit was calculated as the difference between the expected and observed $\mathrm{NO}_{3}^{-}$concentrations (the former was approximately quantified by dividing the apparent oxygen utilization (AOU) with 8.65, the ratio between $\mathrm{O}_{2}$ consumption and $\mathrm{NO}_{3}^{-}$regeneration for aerobic respiration; Richards, 1965). This deficit increased with depth reaching the peak value of just under $15 \mu \mathrm{M}$ in the deepest sample. While all the above parameters exhibited expected depthwise changes, the profile of $\delta^{15} \mathrm{~N}-\mathrm{NO}_{3}^{-}$ deviated greatly from the one expected in a closed system where Rayleigh distillation may be assumed to apply. That is, given the high $\mathrm{NO}_{3}^{-}$deficit in subsurface waters, the $\delta^{15} \mathrm{~N}$ $\mathrm{NO}_{3}^{-}$values should have ranged between 17 and $26 \%$ if the 

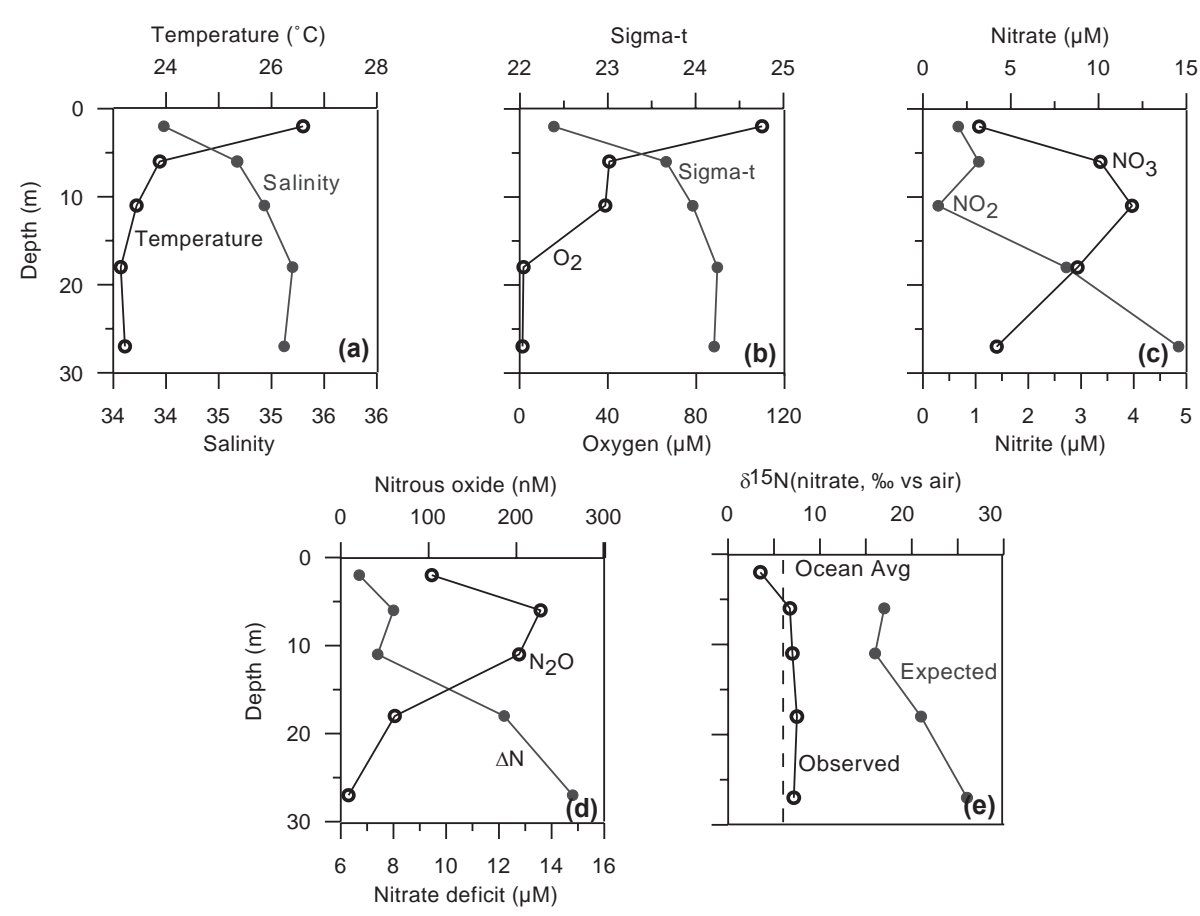

$\delta 15 \mathrm{~N}$ (nitrate, \% vs air)

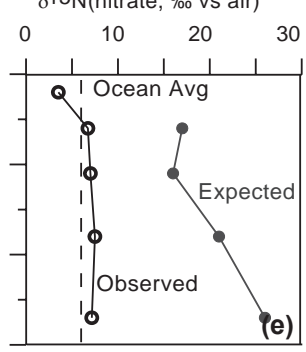

Fig. 8. Vertical profiles of temperature, salinity, density, dissolved $\mathrm{O}_{2}$, inorganic nitrogen species and $\delta^{15} \mathrm{~N}_{\text {of }} \mathrm{NO}_{3}^{-}$(observed as well as expected from the computed $\mathrm{NO}_{3}^{-}$deficits and the reported fractionation factor for the open ocean) at Sta. SS $3939\left(13.126^{\circ} \mathrm{N} ; 74.631^{\circ} \mathrm{E}\right.$; Fig. 1) sampled on 30 August 1997. These data are hitherto unpublished.

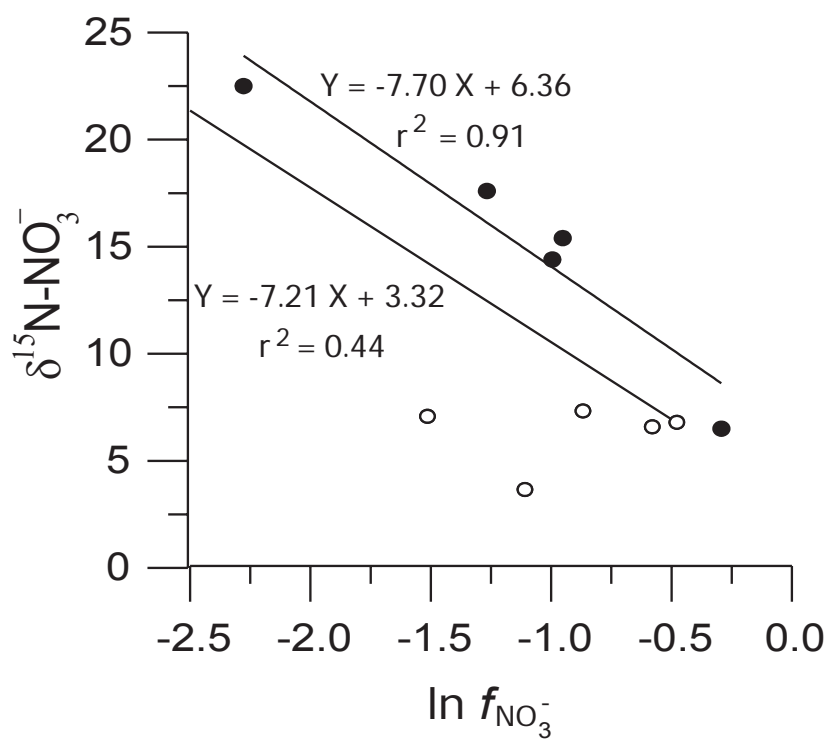

Fig. 9. $\delta^{15} \mathrm{~N}$ of $\mathrm{NO}_{3}^{-}$versus natural $\log$ of fraction of the original $\mathrm{NO}_{3}^{-}$remaining for samples from Sta. SS 3939 (open circles) and Stas. G3-G5 (filled circles). The two regression lines with slopes of -7.70 and -7.21 are for data from Stas. G3-G5 only and those from all stations, respectively. Station locations are shown in Fig. 1. These data are hitherto unpublished.

isotopic fractionation factor reported for the open ocean suboxic zone $(\sim 25 \%$ o) was also applicable to the shallow sub- oxic zone. The values measured were consistently lower. In fact, all the four samples taken from within or below the pycnocline yielded $\delta^{15}{\mathrm{~N}-\mathrm{NO}_{3}^{-}}^{-}$values (6.65 to $7.41 \%$ ) that were quite close to the oceanic average with no depthwise variability. $\mathrm{NO}_{3}^{-}$in the only sample taken from the surface layer was distinctly lighter (3.43\%o).

Several possibilities could be invoked to explain the above observations: (1) Processes responsible for the observed $\mathrm{NO}_{3}^{-}$losses in the coastal suboxic zone may be different from those in its open ocean counterpart. A likely scenario is that a substantial fraction of the loss may occur within the sediments, and the much smaller isotopic fractionation associated with sedimentary denitrification (Brandes and Devol, 2002) could then account for the low $\delta^{15} \mathrm{~N}_{-} \mathrm{NO}_{3}^{-}$values. The few data on sedimentary denitrification, measured mostly during the upwelling period following the acetylene block technique, have yielded values ranging from 0.23 to $1.25 \mathrm{mmol} \mathrm{NO}_{3}^{-} \mathrm{m}^{-2} \mathrm{~d}^{-1}$, which are generally within the range of values from other areas (Naik and Naqvi, 2002). Estimates based on the isotope pairing method are comparable with these values (Naqvi et al., 2006 ${ }^{5}$ ). These rates by themselves appear to be inadequate to account for the observed $\mathrm{NO}_{3}^{-}$loss in the water column. The other processes that may bring about $\mathrm{NO}_{3}^{-}$removal are anammox,

\footnotetext{
${ }^{5}$ Naqvi, S. W. A., Naik, H., Lavik, G., and Kuypers, M. M. M.: Sedimentary denitrification rates over the western Indian continental shelf, in preparation, 2006c.
} 
dissimilatory reduction of $\mathrm{NO}_{3}^{-}$to $\mathrm{NH}_{4}^{+}$(which may also be coupled to anammox) and/or autotrophic denitrification (e.g. reduction of $\mathrm{NO}_{3}^{-}$by species such as $\mathrm{S}^{2-} / \mathrm{HS}^{-}, \mathrm{Fe}^{2+}$ and $\mathrm{Mn}^{2+}$; Luther et al., 1997). Of these at least anammox is expected to be quite important in view of the above-mentioned results from other regions, more so over the Indian shelf where very high $\mathrm{NO}_{2}^{-}$concentrations (maximum $16 \mu \mathrm{M}$ ) are expected to be matched by a high rate of diffusive supply of $\mathrm{NH}_{4}^{+}$from the sediments (Naqvi et al., 2000). (2) Apparently low $\delta^{15} \mathrm{~N}^{-\mathrm{NO}_{3}^{-}}$relative to the $\mathrm{NO}_{3}^{-}$deficit could be produced by mixing of waters. In order to illustrate this possibility the following hypothetical scenario may be considered: A parcel of water is subjected to complete denitrification, thereby resulting in the removal of both ${ }^{15} \mathrm{NO}_{3}^{-}$and ${ }^{14} \mathrm{NO}_{3}^{-}$, followed by rapid 1:1 mixing with the freshly-upwelled water having a $\mathrm{NO}_{3}^{-}$content and $\delta^{15} \mathrm{~N}$ of, say, $24 \mu \mathrm{M}$ and $7 \%$, respectively. The resultant mixture would possess the isotopic characteristics of the upwelled water $\left(\delta^{15} \mathrm{~N}=7 \%\right.$ ) , but it would show a $\mathrm{NO}_{3}^{-}$deficit of $12 \mu \mathrm{M}$. Alternatively, continuous mixing (the open system behaviour) could also result in an underestimation of the fractionation factor. (3) It has been found recently that the reduction of $\mathrm{NO}_{3}^{-}$to $\mathrm{NO}_{2}^{-}$involves huge isotopic discrimination, such that $\delta^{15} \mathrm{~N}$ of $\mathrm{NO}_{2}^{-}$in the suboxic zone of the eastern tropical North Pacific is quite low (K. Casciotti, personal communication). As pointed out, the procedures followed by us actually yields the isotopic composition of $\mathrm{NO}_{3}^{-}$plus $\mathrm{NO}_{2}^{-}$, and so the measured values would be dependent on the ratio between concentrations of the two species. The $\mathrm{NO}_{2}^{-}: \mathrm{NO}_{3}^{-}$ratio is generally much higher in the coastal zone than in the open ocean, and that could contribute to lower $\delta^{15} \mathrm{~N}$ of the combined $\mathrm{NO}_{3}^{-}$and $\mathrm{NO}_{2}^{-}$pool. (4) Finally, it is also possible that if and when the $\mathrm{NO}_{3}^{-}$loss is through heterotrophic denitrification, the fractionation factor associated with the process may not be the same in the coastal and offshore regions. There is some experimental evidence suggesting that the degree of isotopic discrimination may indeed vary with denitrification rate (K.-K. Liu, personal communication).

Unlike the above-mentioned observations off Mangalore, isotopic data off Goa do reveal substantial enrichment of the heavier isotope in residual $\mathrm{NO}_{3}^{-}$(Fig. 9). For these samples the fractionation factor was computed using a simple advection-reaction model that ignores mixing. As the sampling sites were located very close to each other along a coast-perpendicular transect, and the $\mathrm{NO}_{3}^{-}$loss occurred in the upwelled water as it ascended over the shelf, this assumption seems justifiable. The isotopic distribution could thus be modelled with a simple Rayleigh equation (Bender, 1990):

$\delta^{15} \mathrm{~N}-\mathrm{NO}_{3}=10^{3}(\alpha-1) \log _{e} f_{\mathrm{NO} 3}+\left(\delta^{15} \mathrm{~N}-\mathrm{NO}_{3}\right)_{\text {init }}$

where $\mathrm{f}_{\mathrm{NO} 3}$ is the ratio between the observed and expected $\mathrm{NO}_{3}^{-}+\mathrm{NO}_{2}^{-}$concentrations, the latter equaling $\mathrm{AOU} / 8.65$, and $\left(\delta^{15} \mathrm{~N}-\mathrm{NO}_{3}\right)_{\text {init }}$ gives the isotopic composition of the initial (unaltered) material.
The plot of $\delta^{15} \mathrm{~N}-\mathrm{NO}_{3}$ versus $\log _{e} \mathrm{f}_{\mathrm{NO} 3}$ (Fig. 9) indicates a good linear correlation $\left(\mathrm{r}^{2}=0.91\right)$ with the slope of the regression line (value for $\varepsilon_{\text {denit }}$ ) being -7.70 . Inclusion of data from Sta. SS 3939 leads to a little change in the slope $(-7.21)$, but the correlation is deteriorated $\left(r^{2}=0.44\right)$. At the first glance these results appear to support the notion of lower fractionation factor in the coastal suboxic zone. However, as discussed above, the possibility of other factors being also responsible for pulling down the $\delta^{15} \mathrm{~N}$ value of $\mathrm{NO}_{3}^{-}$of coastal waters cannot be ruled out. In fact, it is quite likely that all the factors mentioned above may be in operation, their relative importance varying in space and time. Such a dynamic environment which contrasts the relatively more stable conditions of the open ocean system offers both challenges and opportunities to gain further insights into pathways of oceanic nitrogen cycling.

Acknowledgements. The authors wish to thank their colleagues especially M. D. George, M. D. Kumar, V. V. S. S. Sarma, M. S. Shailaja, D. M. Shenoy and H. S. Dalvi for their contributions to the generation of some of the data presented in this article. Financial support for the establishment of CATS came from the Department of Ocean Development, New Delhi, which is now being sustained under a CSIR Network Project CMM0009. The paper has been substantially benefited by thorough reviews by H. Bange, M. Voss and an anonymous referee.

Edited by: J. Middelburg

\section{References}

Altabet, M. A., Murray, D. W., and Prell, W. L.: Climatically linked oscillations in Arabian Sea denitrification over the past 1 m.y.: Implications for the marine $\mathrm{N}$ cycle, Paleoceanography, 14, 732743, 1999.

Bange, H., Naqvi, S. W. A., and Codispoti, L. A.: The nitrogen cycle in the Arabian Sea, Progr. Oceanogr., 65, 145-168, 2005.

Bange, H. W., Rapsomanikis, S., and Andreae, M. O.: Nitrous oxide cycling in the Arabian Sea, J. Geophys. Res., 106, 1053-1065, 2001.

Bange, H. W., Rixen, T., Johansen, A. M., Siefert, R. L., Ramesh, R., Ittekkot, V., Hoffmann, M. R., and Andreae, M. O.: A revised nitrogen budget for the Arabian Sea, Global Biogeochem. Cycles, 14, 1283-1297, 2000.

Banse, K.: Overview of the hydrography and associated biological phenomena in the Arabian Sea off Pakistan, in: Marine Geology and Oceanography of Arabian Sea and Coastal Pakistan, edited by: Huq, B. U. and Milliman, J. D., Van Nostrand Rheinhold, New York, 271-304, 1984.

Banse, K.: Seasonality of phytoplankton chlorophyll in the central and northern Arabian Sea, Deep-Sea Res., 34, 713-723, 1987.

Barford, C. C., Montoya, J. P., Altabet, M. A., and Mitchell, R.: Steady-state nitrogen isotope effects of $\mathrm{N}_{2}$ and $\mathrm{N}_{2} \mathrm{O}$ production in Paracoccus denitrificans, Appl. Environ. Microbiol., 65, 989994, 1999.

Bender, M. L.: The delta ${ }^{18} \mathrm{O}$ of dissolved $\mathrm{O}_{2}$ in seawater: A unique tracer of circulation and respiration in the deep sea, J. Geophys. Res., 95, 22 243-22 252, 1990. 
Brandes, J. A. and Devol, A. H.: A global marine-fixed nitrogen isotopic budget: Implications for Holocene nitrogen cycling, Global Biogeochem. Cycles, 16, 1120, doi:10.1029/2001GB001856, 2002.

Brandes, J. A., Devol, A. H., Yoshinari, T., Jayakumar, A., and Naqvi, S. W. A.: Isotopic composition of nitrate in the central Arabian Sea and eastern tropical North Pacific: A tracer for mixing and nitrogen cycles, Limnol. Oceanogr., 43, 1680-1689, 1998.

Cline, J. D. and Richards, F. A.: Oxygen deficient conditions and nitrate reduction in the eastern tropical North Pacific Ocean, Limnol. Oceanogr., 17, 885-900, 1972.

Cline, J. D. and Kaplan, I. R.: Isotopic composition of dissolved nitrate during denitrification in the eastern tropical North Pacific Ocean, Mar. Chem., 3, 271-299, 1975.

Codispoti, L. A.: An oceanic fixed nitrogen sink exceeding $400 \mathrm{Tg}$ $\mathrm{N} \mathrm{a}^{-1}$ vs the concept of homeostasis in the fixed-nitrogen inventory, Biogeosciences Discuss., 3, 1203-1246, 2006, http://www.biogeosciences-discuss.net/3/1203/2006/.

Codispoti, L. A. and Christensen, J. P.: Nitrification, denitrification and nitrous oxide cycling in the eastern tropical South Pacific Ocean, Mar. Chem., 16, 277-300, 1985.

Codispoti, L. A., Barber, R. T., and Friederich, G. E.: Do nitrogen transformations in the poleward undercurrent off Peru and Chile have a globally significant influence?, in: Poleward Flows on Eastern Boundaries, edted by: Neshyba, J., Mooers, C., and Barber, R., Springer-Verlag, New York, 281-310, 1989.

Codispoti, L. A., Brandes, J. A., Christensen, J. P., Devol, A. H., Naqvi, S. W. A., Paerl, H. W., and Yoshinari, T.: The oceanic fixed nitrogen and nitrous oxide budgets: Moving targets as we enter the anthropocene?, Sci. Mar., 65, 85-105, 2001.

de Sousa, S. N., Kumar, M. D., Sardesai, S., Sarma, V. V. S. S., and Shirodkar, P. V.: Seasonal variability in oxygen and nutrients in the central and eastern Arabian Sea, Curr. Sci., 71, 847-851, 1996.

Deuser, W. G.: Reducing environments, in: Chemical Oceanography, vol. 3, edited by: Riley, J. P. and Skirrow, G., Academic Press, 1-37, 1975.

Delwiche, C. C. and Steyn, P. L.: Nitrogen isotope fractionation in soils and microbial reactions, Environ. Sci. Technol., 4, 929-935, 1970.

Devol, A. H., Uhlenhopp, A. G., Naqvi, S. W. A., Brandes, J. A., Jayakumar, A., Naik, H., Gaurin, S., Codispoti, L. A., and Yoshinari, T.: Denitrification rates and excess nitrogen gas concentrations in the Arabian Sea oxygen deficient zone, Deep-Sea Res. I, 53, 1533-1547, 2006a.

Devol, A. H., Naqvi, S. W. A., and Codispoti, L. A.: Nitrogen cycling in the suboxic waters of the Arabian Sea, in: Past and Present Water Column Anoxia. NATO Science Series, IV. Earth and Environmental Sciences - Vol. 64, edited by: Neretin, L., Springer, 283-310, 2006b.

Dore, J. E., Popp, B. N., Karl, D. M., and Sasone, F. J.: A large source of atmospheric nitrous oxide from subtropical North Pacific surface waters, Nature, 396, 63-66, 1998.

Farrenkopf, A. and Luther III, G. W.: Iodine chemistry reflects productivity and denitrification in the Arabian Sea: evidence for flux of dissolved species from sediments of western India into the OMZ, Deep-Sea Res. II, 49, 2303-2318, 2002.

Farrenkopf, A., Luther III, G. W., Truesdale, V. W., and van der
Weijden, C. H.: Sub-surface iodide maxima: evidence for. biologically catalysed redox cycling in in the Arabian Sea OMZ during the SW intermonsoon, Deep-Sea Res. II, 44, 1391-1409, 1997.

Flagg, C. N. and Kim, H. -S.: Upper ocean currents in the northern Arabian Sea from shipboard ADCP measurements collected during the 1994-1996 U.S. JGOFS and ONR programs, Deep-Sea Res. II, 45, 1917-1959, 1998.

Garrison, D. L., Gowing, M. M., and Hughes, M. P.: Nano- and microplankton in the northern Arabian Sea during the southwest monsoon, August-September 1995: a US JGOFS study, DeepSea Res. II, 45, 2269-2299, 1998.

Gruber, N. and Sarmiento, J. L.: Global patterns of marine nitrogen fixation and denitrification, Global Biogeochem. Cycles, 11, 235-266, 1997.

Gruber, N. and Sarmiento, J. L.: Biogeochemical/physical interactions in elemental cycles, in: The Sea, Vol. 12, edited by: Robinson, A. R., McCarthy, J. J., and Rothschild, B. J., John Wiley \& Sons, New York, 337-399, 2002.

Helly, J. J. and Levin, L. A.: Global distribution of naturally occurring marine hypoxia on continental margins, Deep-Sea Res. I, 51, 1159-1168, 2004.

Hattori, A.: Denitrification and dissimilatory nitrate reduction, in: Nitrogen in the Marine Environment, edited by: Carpenter, E. J. and Capone, D., Academic Press, New York, 191-232, 1983.

Hutchins, D. A. and Bruland, K. W.: Iron-limited diatom growth and $\mathrm{Si}: \mathrm{N}$ uptake ratios in a coastal upwelling regime, Nature, 393, 561-564, 1998.

Kim, K. -R. and Craig, H.: Two isotope characterization of $\mathrm{N}_{2} \mathrm{O}$ in the Pacific Ocean and constraints on its origin in deep water, Nature, 347, 58-61, 1990.

Kim, H.-S., Flagg, C. N., and Howden, S. D.: Northern Arabian Sea variability from TOPEX/Poseidon altimetry data: An extension of the US JGOFS shipboard ADCP study, Deep-Sea Res. II, 48, 1069-1096, 2001.

Kuypers, M. M. M., Sliekers, A. O., Lavik, G., Schmid, M., Jørgensen, B. B., Kuenen, J. G., Sinninghe Damste, J. S., Strous, M., and Jetten, M. S. M.: Anaerobic ammonium oxidation by anammox bacteria in the Black Sea, Nature, 422, 608-611, 2003

Kuypers, M. M. M., Lavik, G., Wöbken, D., Schmid, M., Fuchs, B. M., Amann, R., Jørgensen, B. B., and Jetten, M. S. M.: Massive nitrogen loss from the Benguela upwelling system through anaerobic ammonium oxidation, Proc. Nat. Acad. Sci., 102, 64786483, 2005.

Law, C. S. and Owens, N. J. P.: Significant flux of atmospheric nitrous oxide from the northwest Indian Ocean, Nature, 346, 826828, 1990.

Luther III, G. W., Sundby, B., Lewis, B. L., Brendel, P. J., and Silverberg, N.: Interactions of manganese with the nitrogen cycle: Alternative pathways to dinitrogen, Geochim. Cosmochim. Acta, 61, 4043-4052, 1997.

Mantoura, R. F. C., Law, C. S., Owens, N. J. P., Burkill, P. H., Woodward, E. M. S., Howland, R. J. M., and Llewellyn, C. A.: Nitrogen biogeochemical cycling in the northwestern Indian Ocean, Deep-Sea Res. II, 40, 651-671, 1993.

Mariotti, A., Germon, J. C., Hubert, P., Kaiser, P., Letolle, R., Tardieux, A., and Tardieux, P.: Experimental determination of nitrogen kinetic isotope fractionation: some prinicples; illustration for the denitrfication and nitrification processes, Plant Soil, 
62, 413-430, 1981.

Morrison, J. M., Codispoti, L. A., Gaurin, S., Jones, B., Manghnani, V., and Zheng, Z.: Seasonal variation of hydrographic and nutrient fields during the US JGOFS Arabian Sea Process Study, Deep-Sea Res. II, 45, 2053-2101, 1998.

Morrison, J. M., Codispoti, L. A., Smith, S. L., Wishner, K., Flagg, C., Gardner, W. D., Gaurin, S., Naqvi, S. W. A., Manghnani, V., Prosperie, L., and Gundersen, J. S.: The oxygen minimum zone in the Arabian Sea during 1995, Deep-Sea Res. II, 46, 19031931, 1999.

Naik, H. and Naqvi, S. W. A.: Sedimentary nitrogen cycling over the western continental shelf of India, EOS - Trans. Amer. Geophys. Union, 83(4) OSM Suppl., Abs. OS12I-05, 2002.

Naqvi, S. W. A.: Some aspects of the oxygen-deficient conditions and denitrification in the Arabian Sea, J. Mar. Res., 49, 10491072, 1987.

Naqvi, S. W. A.: Geographical extent of denitrification in the Arabian Sea in relation to some physical processes, Oceanolog. Acta, 14, 281-290, 1991.

Naqvi, S. W. A. and Noronha, R. J.: Nitrous oxide in the Arabian Sea, Deep-Sea Res., 38, 871-890, 1991.

Naqvi, S. W. A. and Shailaja, M. S.: Activity of the respiratory electron transport system and respiration rates within the oxygen minimum layer of the Arabian Sea, Deep-Sea Res. II, 40, 687695, 1993.

Naqvi, S. W. A., Noronha, R. J., Somasundar, K., and Sen Gupta, R.: Seasonal changes in the denitrification regime of the Arabian Sea, Deep-Sea Res., 37, 693-711, 1990.

Naqvi, S. W. A., Yoshinari, T., Jayakumar, D. A., Altabet, M. A., Narvekar, P. V., Devol, A. H., Brandes, J. A., and Codispoti, L. A.: Budgetary and biogeochemical implications of $\mathrm{N}_{2} \mathrm{O}$ isotope signatures in the Arabian Sea, Nature, 394, 462-464, 1998a.

Naqvi, S. W. A., Yoshinari, T., Brandes, J. A., Devol, A. H., Jayakumar, D. A., Narvekar, P. V., Altabet, M. A., and Codispoti, L. A.: Nitrogen isotopic studies in the suboxic Arabian Sea, Proc. Indian Acad. Sci. (Earth Planet. Sci.), 107, 367-378, 1998 b.

Naqvi, S. W. A., Jayakumar, D. A., Narvekar, P. V., Naik, H., Sarma, V. V. S. S., D'Souza, W., Joseph, S., and George, M. D.: Increased marine production of $\mathrm{N}_{2} \mathrm{O}$ due to intensifying anoxia on the Indian continental shelf, Nature, 408, 346-349, 2000.

Naqvi, S. W. A., Sarma, V. V. S. S., and Jayakumar, D. A.: Carbon cycling in the northern Arabian Sea during the northeast monsoon: Significance of salps, Mar. Ecol. Progr. Ser., 226, 35-44, 2002.

Naqvi, S. W. A, Naik, H., Jayakumar, D. A., Shailaja, M. S., and Narvekar, P. V.: Seasonal oxygen deficiency over the western continental shelf of India, in: Past and Present Water Column Anoxia. NATO Science Series, IV. Earth and Environmental Sciences - Vol. 64, Springer, 195-224, 2006a.

Naqvi, S. W. A., Naik, H., D' Souza, W., Narvekar, P. V., Paropkari, A. L., and Bange, H. W.: Carbon and nitrogen fluxes in the North Indian Ocean, in: Carbon and Nutrient Fluxes in Continental Margins: A Global Synthesis, edited by: Liu, K. K., Atkinson, L., Quinones, R., and Talaue-McManus, L., SpringerVerlag, Berlin, in press, 2006b.

Richards, F. A.: Anoxic basins and fjords, in: Chemical Oceanography, Vol. 1, edited by: Riley, J. P. and Skirrow, G., Academic Press, London, 611-643, 1965.

Rixen, T., Guptha, M. V. S., and Ittekkot, V.: Deep ocean fluxes and their link to surface ocean processes and the biological pump, Prog. Oceanogr., 65, 240-259, 2005.

Saager, P. M., de Baar, H. J. W., and Burkill, P. H.: Manganese and iron in Indian Ocean waters, Geochim. Cosmochim. Acta, 53, 2259-2267, 1989.

Senga, Y., Mochida, K., Fukumori, R., Okamoto, N., and Seike, Y.: $\mathrm{N}_{2} \mathrm{O}$ accumulation in estuarine and coastal sediments: the influence of $\mathrm{H}_{2} \mathrm{~S}$ on dissimilatory nitrate reduction, Estuar. Coast. Shelf Sci., 67, 231-238, 2006.

Sen Gupta, R. and Naqvi, S. W. A.: Chemical oceanography of the Indian Ocean, north of the equator, Deep-Sea Res., 31, 671-706, 1984.

Shailaja, M. S., Narvekar, P. V., Alagarsamy, R., and Naqvi, S. W. A.: Nitrogen transformations as inferred from the activities of key enzymes in the Arabian Sea oxygen minimum, Deep-Sea Res. I, 53, 960-970, 2006.

Siefert R. L., Johansen, A. M., and Hoffmann, M. R.: Chemical characterization of ambient aerosol collected during the southwest Monsoon and inter-Monsoon seasons over the Arabian Sea: Labile Fe(II) and other trace metals, J. Geophys. Res., 104, 3511-3526, 1999.

Sigman, D. M., Altabet, M. A., Michener, R., McCorkle, D. C., Fry, B., and Holmes, R. M.: Natural abundance-level measurement of the nitrogen isotopic composition of oceanic nitrate: an adaptation of the ammonia diffusion method, Mar. Chem., 57, 227-242, 1997.

Somasundar, K. and Naqvi, S. W. A.: On the renewal of the denitrifying layer in the Arabian Sea, Oceanolog. Acta, 11, 167-172, 1988.

Swallow, J.: Some aspects of the physical oceanography of the Indian Ocean. Deep-Sea Res., 31, 639-650, 1984.

Tanaka, T. and Saino, T.: Modified method for the analysis of nitrogen isotopic composition of oceanic nitrate at low concentration, J. Oceanogr., 58, 539-546, 2002.

Thamdrup, B., Dalsgaard, T., Jensen, M. M., Ulloa, O., Farias, L., and Escribano, R.: Anaerobic ammonium oxidation in the oxygen-deficient waters off northern Chile, Limnol. Oceanogr., 51, 2145-2156, 2006.

Wiggert, J. D., Murtugudde, R. G., and Christian, J. R.: Annual ecosystem variability in the tropical Indian Ocean: Results of a coupled bio-physical ocean general circulation model, Deep-Sea Res. II, 53, 644-676, 2006.

Wu, J., Calvert, S. E., and Wong, C. S.: Nitrogen isotope variations in the subarctic northeast Pacific: relationships to nitrate utilization and trophic structure, Deep-Sea Res. I, 44, 287-314, 1997.

Wyrtki, K.: Oceanographic Atlas of the International Indian Ocean Expedition, National Science Foundation, Washington, D.C., $531 \mathrm{pp}, 1971$.

Yamagishi, H., Yoshida, N., Toyoda, S., Popp, B. N., Westley, M. B., and Watanabe, S.: Contributions of denitrification and mixing on the distribution of nitrous oxide in the North Pacific, Geophys. Res. Lett., 32, L04603, doi:10.1029/2004GL021458, 2005.

Yoshinari, T., Altabet, M. A., Naqvi, S. W. A., Codispoti, L. A., Jayakumar, A., Kuhland, M., and Devol, A. H.: Nitrogen and oxygen isotopic composition of $\mathrm{N}_{2} \mathrm{O}$ from suboxic waters of the eastern tropical North Pacific and the Arabian Sea - measurement by continuous-flow isotope ratio monitoring, Mar. Chem., 56, 253-264, 1997. 